\title{
Carol V. Ruppé Distinguished Service Award: Alasdair Brooks
}

\author{
Audrey Horning
}

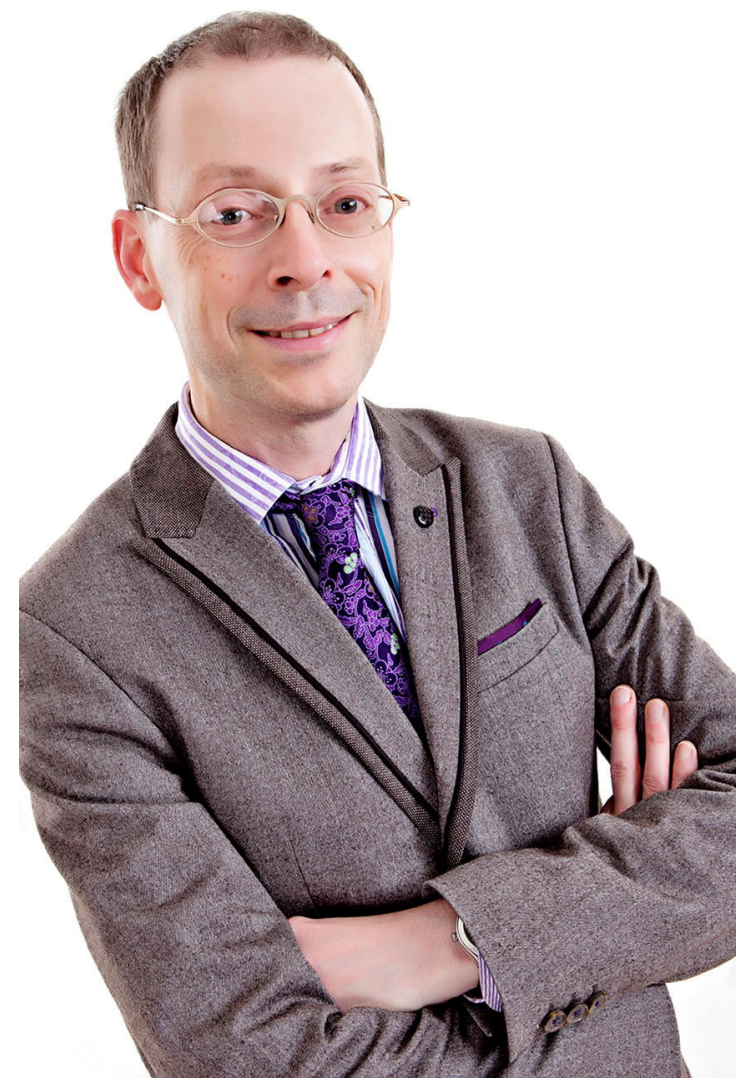

A. Horning $(\bowtie)$

Department of Anthropology, College of William and Mary, PO Box 8795, Williamsburg, VA 23187-8795, U.S.A.

e-mail: ajhorn@wm.edu
The Carol V. Ruppé Distinguished Service Award was established in 1990 to recognize individuals who have given sustained and truly outstanding service to the Society for Historical Archaeology (SHA). In January 2018, at the 51st Annual Conference on Historical and Underwater Archaeology held in New Orleans, the SHA presented this award to an extremely deserving individual, Dr. Alasdair Brooks, in recognition of his long history of distinguished service and for his role as an exemplary steward and champion of global historical archaeology.

Alasdair Brooks has been an active member of the SHA since 1990, the same year he graduated from St. Mary's College of Maryland in St. Mary's City. There, one of his early influences was Dr. Julia King, the recipient of the 2018 Harrington Medal. Alasdair is perhaps best known to most SHA members as editor of the SHA Newsletter, a role that he has held since 2008. In addition, he has been a member of the SHA Board of Directors since 2008, one of the chairs of the SHA Communications Editors' Advisory Committee, and a member of numerous committees, including the SHA Collections and Curation and Budget committees. Alasdair brought great energy and organization to his role as newsletter editor, not only efficiently producing the publication, but overseeing the transition from a print edition to a digital edition. Even more significantly, Alasdair worked tirelessly to expand the newsletter's international reach and content. An abiding commitment to international engagement lies at the core of Alasdair's service to the discipline of historical archaeology. He is a firm and vocal supporter of the need for 
North American archaeologists to become more aware of and engaged with the scholarship being produced elsewhere in the world, as well as a firm and effective advocate for the SHA both within and outside North America. He has been unwavering in his encouragement of and support for scholars located outside the traditional core of the discipline, actively seeking out new contacts and working to ensure their inclusion in the activities of the SHA, to the benefit of all.

Alasdair Brooks's contributions to the SHA extend well beyond the newsletter. In 2013, Alasdair served as the program chair for the annual conference held in Leicester, England. Writing from experience as the conference co-chair for that meeting, I can honestly say that there would not have been a conference without Alasdair's vision, encouragement, practical knowledge, and experience. He, in effect, did double duty as program chair and as a conduit between the local committee and the SHA board. A lesser soul might have struggled to maintain those two roles, given the challenges of balancing the needs and expectations of all concerned when organizing the conference in a small English city where North American-style conference facilities were not readily available. Alasdair, however, wore both hats with aplomb, diffusing any anxieties with his indomitable sense of humor, as well as his professionalism and keen attention to detail. Most notable of his contributions to the conference program was the plenary session that he put together to reflect the theme of globalization, immigration, and transformation. For that session, Alasdair proactively reached out to and incorporated scholars from every inhabited continent on the planet. Notably and remarkably, he also personally led the editing and the production of the papers from the plenary session as a special issue of the SHA journal Historical Archaeology, published immediately after the 2013 conference (Brooks and Casella 2013). Alasdair is also serving as program chair for the forthcoming 2021 SHA annual meeting in Lisbon, further demonstrating both his commitment to the SHA and to expanding the discipline globally.

Alasdair's professional career experience itself is unparalleled in its global nature. Raised variously in Belgium, the United Kingdom, Iceland, and the United States, Alasdair has worked as an historical archaeologist and specialist in British ceramics and material culture study in the United Kingdom, the United States, Jamaica, Australia, Venezuela, Argentina, the United Arab
Emirates, Qatar, and Oman. In his own contribution to the Leicester plenary volume, aptly titled "The World Is What It Is" (a quote from A Bend in the River by the Nobel laureate V. S. Naipaul), Alasdair reflected upon his own positionality in the discipline, acknowledging that

our personal experiences, both the manner in which we archaeologists have lived in the modern world and where we have lived in the modern world, inevitably color our perception of and approach to archaeologies of globalization and immigration, and the transformations brought about by both. (Brooks 2013:1)

Alasdair's personal scholarship very much reflects his global perspective and experience. His ability to substantively link seemingly disparate patterns of ceramic trade and consumption in the Americas, Australasia, and Europe speaks to his ability to conceptualize historical archaeology at all scales of analysis, from the very local to the undeniably global. Alasdair has a long and impressive record of publishing in the journal, as well as organizing conference sessions. Papers from one such session, coorganized with Natascha Mehler of the University of Vienna and appropriately focusing on historical archaeologies of nationalism, were published this past year by the University of Florida Press (Brooks and Mehler 2017). The perspective Alasdair has gained from his international exposure to multiple ways of studying the past and interpreting its value in the present has been and continues to be invaluable to the SHA as it grows and internationalizes. Furthermore, in every place he has worked and lived, Alasdair has contributed to the enhancement of practice in historical archaeology. For example, he was recently part of the team building, from scratch, the new Saruq al Hadid Archaeology Museum in Dubai, also helping to provide curatorial training. Currently, he is employed by the British Red Cross as its heritage manager, overseeing its museum and archives team.

Further illustrative of Alasdair's wholehearted dedication to global historical archaeology is the fact that, in addition to his considerable service to the SHA, he also continues to give extensively of his time and dedication to the SHA's sister society, the Society for PostMedieval Archaeology (SPMA). Alasdair served as the editor for the journal Post-Medieval Archaeology from 2013 to 2017, and he is now an ordinary member of the SPMA Council. 
The level of Alasdair's professional service to the discipline is impressive by any measure. That he has also continued to work tirelessly and without interruption for the SHA and other organizations as his career has led him to undertake frequent international moves is nothing short of remarkable. The SHA, and the discipline of historical archaeology more generally, would be much the poorer without the service, dedication, and multiple contributions made by Alasdair Brooks, and in particular his leadership in building a truly global community of historical archaeologists. Alasdair Brooks is an extremely worthy recipient of the Carol V. Ruppé Distinguished Service Award.

Open Access This article is distributed under the terms of the Creative Commons Attribution 4.0 International License (http:// creativecommons.org/licenses/by/4.0/), which permits unrestricted use, distribution, and reproduction in any medium, provided you give appropriate credit to the original author(s) and the source, provide a link to the Creative Commons license, and indicate if changes were made.

\section{References}

Brooks, Alasdair

2013 The World Is What It Is: The Role of Subjectivity and Personal Experience in Global Historical Archaeologies. In Globalization, Immigration, Transformation, Alasdair Brooks and Eleanor Conlin Casella, editors. Thematic issue, Historical Archaeology 47(1):1-9.

Brooks, Alasdair, and Eleanor Conlin Casella (editors)

2013 Globalization, Immigration, Transformation. Thematic issue, Historical Archaeology 47(1).

Brooks, Alasdair, and Natascha Mehler

2017 The Country Where My Heart Is: Historical Archaeologies of Nationalism and National Identity. University of Florida Press, Gainesville. 